\title{
SISTEM EKONOMI PERKEBUNAN: PERSISTENSI KETERGANTUNGAN NEGARA DUNIA KETIGA
}

\section{(ECONOMIC PLANTATION SYSTEM: A PERSISTENCE OF THE THIRD COUNTRIES DEPENDENCE)}

\author{
Heru Purwandari \\ Departemen Sains Komunikasi dan Pengembangan Masyarakat \\ Fakultas Ekologi Manusia \\ Institut Pertanian Bogor \\ Email: heru_purwandari@yahoo.com
}

\begin{abstract}
There was changing in dependency of the economic plantations system in along time. Two phenomena which always occur is the smallholding estate system are poverty and underdevelopment. In the colonial period, though plantation integrated to the external world, but farmer plantation never change from dependency situation which was created by colonial government. At present, when globalization become ideology that condition has not change. In the makro context, dependency in plantation on colonial period was showed by authority for source of economic. At present, dependency have influence in political government. All of government programs have implication in stagnancy of dependency nature.
\end{abstract}

Key words: dependency, plantation, poverty, and underdevelopment

\section{PENDAHULUAN}

Fenomena ketergantungan dalam sejarah ekonomi Indonesia dapat ditelusuri dari kondisi perkebunan. Sejak kemunculannya pada masa kolonial, karakteristik perkebunan tampak khas karena disamping memiliki ciri struktur internal negara, yang terkait dengan produksi dan tenaga kerja, juga terlibat dengan dunia luar dan terintegrasi dengan sistem ekonomi dunia. Sejak abad ke-16 sampai abad ke-20 dinamika perkebunan terkait dengan perkembangan pola perkebunan yang selalu mengalami masa penyesuaian dari masa kolonial hingga kemerdekaan.

Perjalanan sejarah menunjukkan bahwa perkebunan selalu terkait dengan ekonomi internasional namun dengan mekanisme yang berbeda pada masingmasing jaman tersebut. Pada masa kolonial, hubungan perkebunan dengan dunia internasional relatif bersifat langsung. Perkebunan yang ada di Negara Dunia Ketiga membawa aliran bahan mentah secara langsung ke perdagangan dunia, melalui tangan penjajah. Bentuk ini dalam tulisannya Tauchid (1953) dimaksudkan untuk tetap mendudukkan Negara Dunia Ketiga sebagai negara 
dengan ketergantungan yang tinggi terhadap penjajah. Petani dibiarkan menjadi buruh yang juga memiliki sifat borjuis lokal supaya tidak ada keinginan untuk membangkang terhadap pemilik perkebunan yakni penjajah.

Gambaran demikian didukung oleh fakta fenomena kemiskinan yang dialami oleh penduduk yang bekerja sebagai buruh. Sesuatu yang kontradiktif mengingat perkebunan merupakan sebuah bidang usaha yang terintegrasi kedalam sistem ekonomi yang lebih besar, meliputi regional bahkan dunia. Hal tersebut dapat dilihat pada mekanisme ketergantungan terutama tentang penetapan harga yang diserahkan pada negara maju bagi komoditas dengan karakteristik tertentu, pengiriman teknologi, tenaga ahli, dan juga modal.

Pendekatan analisis ketergantungan dalam bidang perkebunan berbeda antara masa kolonial dengan masa sekarang. Jika pada masa kolonial pendekatan lebih pada dimensi ekonomi, maka pada masa sekarang, porsi sosial-politik merupakan dasar analisis yang lebih tepat digunakan untuk melihat fenomena ketergantungan yang terjadi. Tangan-tangan elit yang berada di center of periphery memainkan perannya dalam perdagangan. Kajian ini mendapat porsi tersendiri dalam ranah teori dependensi modern yang memusatkan perhatian pada dimensi sosial-politik dari kondisi ketergantungan negara Dunia Ketiga.

Secara ringkas, permasalahan mendasar yang ingin dikaji dalam tulisan ini adalah bagaimana mekanisme ketergantungan tercipta dari karakteristik perkebunan dan perubahan struktur yang terjadi didalamnya. Dalam kaitannya dengan alur distribusi komoditas perkebunan, mekanisme yang ada dipengaruhi oleh dinamika ekonomi dunia. Dengan demikian tulisan ini sekaligus berupaya menggambarkan keterkaitan ekonomi dengan dinamika ekonomi dunia. Adapun tujuan tulisan ini adalah mengetahui sejauh mana posisi Indonesia dalam ekonomi dunia terkait dengan komoditas perkebunan. Disamping itu, tulisan ini juga dimaksudkan untuk mengetahui bagaimana mekanisme dipertahankannya ketergantungan negara Dunia Ketiga melalui sektor perkebunan. Secara teoritis, tulisan ini berupaya menggambarkan aspek teori ketergantungan yang terjadi dalam hubungan dua negara yang bersumber dari sektor perkebunan sebagai bagian dari komoditas perdagangan internasional.

\section{KERANGKA TEORETIS}

Secara garis besar tulisan ini menggunakan pendekatan teori dependensi baru serta dianalisis dalam konteks makro dunia dengan menggunakan perspektif sistem dunia. Dua pendekatan teori tersebut dimaksudkan untuk memperdalam analisis kajian karakteristik perkebunan yang menjadi fokus analisis. Karakteristik yang khas dari perkebunan terletak pada sifat komoditasnya yang merupakan bagian dari komoditas perdagangan dunia sehingga dipandang perlu melihat sejauh mana perspektif sistem dunia digunakan sebagai alat analisis.

64 | Heru Purwandari. Sistem Ekonomi Perkebunan : Persistensi Ketergantungan... 
Ketergantungan didefinisikan sebagai hubungan dua negara atau lebih yang mengandung bentuk ketergantungan jika beberapa negara (yang dominan) dapat berkembang dan memiliki otonomi dalam pembangunannya, sementara negara lainnya (yang tergantung) melakukan hal serupa hanya sekadar refleksi perkembangan negara dominan. Frank dalam Suwarsono dan So (2000) bahkan mendefinisikan ketergantungan sebagai kondisi yang dialami oleh satelit ketika berhubungan dengan metropole. Pola hubungan antara dua negara tersebut bersifat asimetris. Negara yang satu memiliki kekuatan yang lebih (metropole) dibanding negara lainnya (satelit). Ketergantungan yang terwujud dapat ditunjukkan melalui ketergantungan modal, teknologi, dan tenaga ahli. Hal tersebut sebagai dampak dari proses pembangunan yang memihak pada negara maju.

Pada awal perkembangannya, teori ketergantungan memusatkan perhatian pada terjadinya keterbelakangan yang dialami negara miskin akibat kontak dengan negara maju. Frank (1984) membuat pembagian melalui apa yang disebutnya sebagai negara-negara metropolis maju dan negara-negara satelit yang terbelakang. Hubungan ekonomi antara negara metropolis maju dan negara satelit terbelakang merupakan aspek utama perkembangan sistem kapitalis dalam skala internasional. Frank tidak dapat menerima pendapat yang mengatakan bahwa perkembangan ekonomi negara miskin akan terjadi sebagai akibat hubungan ekonomi seperti demikian yang akan menimbulkan difusi modal, teknologi, nilai-nilai institusi dan faktor dinamis lainnya kepada negara miskin. Metropolis di negara-negara miskin, baik yang berada di tingkat nasional maupun tingkat lokal dikuasai oleh pihak yang pada hakekatnya bertugas mempertahankan struktur monopolis dan eksploitatif yang berakar dari sifat hubungan antara metropolis dunia dan negara miskin. Melalui ciri perkebunan, Beckford (1972) memberikan keterangan bahwa hasil ekspor bahan mentah yang dialirkan oleh negara terbelakang tidak mencukupi untuk memenuhi kebutuhan pangan yang harus diimport oleh negara terbelakang. Hal ini berarti ada ketidaksamaan nilai tukar komoditas yang dihasilkan oleh kedua negara tersebut.

Merujuk pada paparan di atas, nyata bahwa sifat dasar eksploitatif menciptakan kondisi keterbelakangan di negara berkembang sebagai hasil kontak dengan negara maju. Kontak tersebut melahirkan pola hubungan dua negara yang asimetris dan tidak sama kuat yang kemudian menimbulkan ketergantungan. Pada awal perkembangannya hubungan antara negara maju dan berkembang merupakan hubungan kolonialisme dan imperialisme. Kajian teori dependensi yang lebih menitikberatkan pada analisis kesejarahan negara Dunia Ketiga menunjukkan bahwa kesejarahan turut mengukir dan memberi warna pada kondisi negara Dunia Ketiga pada masa sekarang. Asumsi dasar teori ketergantungan dapat dilihat sebagai berikut:

Pertama, keadaan ketergantungan dilihat sebagai suatu gejala yang sangat umum, berlaku bagi seluruh negara Dunia Ketiga. Teori dependensi berusaha menggambarkan watak-watak umum keadaan ketergantungan di negara Dunia 
Ketiga sepanjang sejarah perkembangan kapitalisme dari Abad XVI sampai sekarang.

Kedua, ketergantungan dilihat sebagai kondisi yang diakibatkan oleh "faktor luar". Sebab terpenting yang menghambat pembangunan karenanya tidak terletak pada persoalan kekurangan modal atau kekurangan tenaga dan semangat wiraswasta, melainkan terletak di luar jangkauan politik-ekonomi dalam negeri suatu negara. Warisan sejarah kolonial dan pembagian kerja yang timpang bertanggung jawab terhadap kemandekan pembangunan negara Dunia Ketiga.

Ketiga, permasalahan ketergantungan lebih dilihat sebagai masalah ekonomi yang terjadi akibat mengalirnya surplus ekonomi dari negara Dunia Ketiga ke negara maju. Karena kawasan pinggiran kehilangan surplusnya, yang justru dimanfaatkan oleh pusat untuk tujuan pembangunan, pembangunan di pusat mengakibatkan keterbelakangan di kawasan pinggiran.

Keempat, situasi ketergantungan merupakan bagian yang tak terpisahkan dari proses polarisasi regional ekonomi global. Di satu pihak, mengalirnya surplus ekonomi dari Dunia Ketiga menyebabkan keterbelakangan, sementara hal yang sama merupakan salah satu, bahkan mungkin satu-satunya faktor yang mendorong lajunya pembangunan di negara maju. Dengan kata lain, keterbelakangan di negara Dunia Ketiga dan pembangunan negara maju menyebabkan terjadinya polarisasi regional dalam tatanan ekonomi global.

Kelima, ketergantungan dilihat sebagai suatu hal yang bertolak belakang dengan pembangunan. Kendala terpenting bagi pembangunan bukanlah kurangnya modal atau kemampuan kewirausahaan, melainkan harus ditemukan dalam pembagian kerja internasional yang nyata-nyata tidak adil.

Jika dilihat gambaran teori dependensi klasik, tampak bahwa dimensi ekonomi menjadi fokus yang mendasari pemahaman tentang ketergantungan negara Dunia Ketiga. Berbeda dengan apa yang dilakukan oleh penganut teori dependensi baru. Meskipun sama-sama memusatkan perhatian pada kondisi ketergantungan negara Dunia Ketiga, dependensi baru melihatnya dari dimensi sosial-politik. Perbedaan mendasar lain antara kedua teori dependensi tersebut terlihat pada penyebab utama ketergantungan. Dependensi klasik melihat ketergantungan sebagai pola hubungan asimetris yang disebabkan oleh faktor eksternal, sedangkan dependensi baru melihat bahwa faktor eksternal dan internal menjadi penyebab ketergantungan di negara Dunia Ketiga.

Kritik atas dependensi klasik dipaparkan pertama kali oleh Cardoso. Cardoso sebagai tokoh utama teori dependensi baru lebih tertarik untuk melihat aspek sosial-politik dari ketergantungan, khususnya analisa perjuangan kelas dan konflik kelompok, dan pergerakan politik. Cardoso melihat bahwa faktor internal berkaitan dengan faktor eksternal. Secara tegas dikatakan bahwa "hubungan antara kekuatan intern dan kekuatan ekstern membentuk satu bangunan yang keterkaitan strukturnya dapat dijumpai pada keterkaitan antara kelas sosial lokal dominan dan kelas sosial internasional. Dominasi ekstern akan mewujud sebagai kekuatan intern, melalui berbagai perilaku sosial dari kelas 
sosial dominan yang hendak memaksakan tercapainya tujuan dan kepentingan asing. Analisa ini oleh Cardoso disebut sebagai "internalisasi kepentingan ekstern".

Menurut Cardoso, perkembangan politik-ekonomi negara Dunia Ketiga telah sampai pada fase baru dengan kemunculan perusahaan multinasional, penyebaran industri padat modal ke negara pinggiran, dan pembagian kerja internasional. Model pembangunan bergantung-nya Cardoso akan selalu dipaksa untuk menggunakan teknologi impor yang sudah hampir dapat dipastikan merupakan teknologi padat modal. Ekspansi dan akumulasi modal domestik memerlukan dan bahkan tergantung pada faktor-faktor yang berada di luar jangkauannya. Modal domestik ini harus ikut serta dan mengikuti gerak dan irama perputaran modal internasional.

Dengan demikian perbedaan antara dependensi klasik dengan dependensi baru bukan pada ketergantungan namun lebih pada mekanisme dan pola-pola ketergantungan yang terjadi. Pada kedua teori tersebut, hubungan satelitmetropolis tetap ada dengan mekanisme pengambilan surplus ekonomi oleh negara maju. Keseluruhan rangkaian hubungan satelit-metropolis dibangun hanya untuk melakukan pengambilan surplus ekonomi (dalam bentuk bahan mentah, bahan tambang, barang dagangan, laba, dan sebagainya. Gambaran khas dependensi baru terutama terletak pada kemampuannya untuk menganalisis situasi konkret negara Dunia Ketiga. Teori ini akan diarahkan untuk melihat asal mula timbulnya ketergantungan sekaligus melihat sejarah perubahannya.

Pemikiran Cardoso tentang pembangunan dan keterbelakangan pada Negara Dunia Ketiga sebagai efek organisasi internasional menjadi pijakan perspektif sistem dunia. Dalam kasus ini, teori ketergantungan menjadi semacam batu loncatan untuk dapat pindah ke teori sistem dunia. Perspektif sistem-dunia mempelajari dinamika sejarah sistem ekonomi dunia. Untuk hal ini, Wallerstein berpendapat bahwa sistem ekonomi kapitalis dunia ini berkembang melalui kecenderungan sekularnya (secular trends) yang meliputi proses pencaplokan (incorporation), komersialisasi agraria, industrialisasi, dan proletarianisasi. Bersamaan dengan ini, sistem ekonomi dunia juga memiliki apa yang disebut dengan irama perputaran (the cyclical rhythms), yakni irama ekspansi dan stagnasi yang terjadi sebagai akibat ketidakseimbangan permintaan dan penawaran barang dunia. Dalam konteks perkebunan yang menghasilkan komoditas perdagangan dunia, ketidakseimbangan antara permintaan dan penawaran di tingkat dunia akan mempengaruhi alur distribusi komoditas. Bagi Wallerstein dinamika sistem dunia yakni kapitalisme global selalu memberikan peluang bagi negara yang ada untuk naik atau turun kelas. Negara bisa melakukan mobilitas vertikal sebagai sebuah dinamika dalam sistem dunia. Hal tersebut berarti, dinamika ekonomi dunia akan mempengaruhi posisi sebuah negara sebagai akibat negara dan sistem ekonomi dunia merupakan sesuatu yang terhubung. Imperialisme gaya baru yang 'ditawarkan' negara maju dengan ciri-ciri teori Lenin dimana terdapat dominasi ekonomi negara maju terhadap nDK menghasilkan sebuah kontrol negara maju 
terhadap nDK yang dilandasi oleh dua faktor yakni pergerakan modal dan proses produksi. Keduanya selain memiliki keterkaitan satu sama lain juga memiliki keterkaitan dengan transformasi ekonomi global dalam sistem kapitalisme yang memegang peranan penting dalam mengontrol sistem produksi melalui keuangan.

Konsep sistem dunia membantu peneliti untuk menguji dinamika global. Sistem kapitalis dunia yang menjadi sistem dunia terkandung hubungan global. Sebagai implikasi dari sistem ekonomi global, maka basis universal dalam perspektif sistem dunia bukan lagi terletak pada pembangunan dan modernisasi melainkan pada demokrasi dan pasar bebas. Prinsip demikian menunjukkan bahwa negara tidak mungkin keluar dari hubungan imperialisme dalam berbagai bentuk.

Sistem dunia memiliki kategori teoritis dan definisi operasional yang dibatasi pada lima aspek yakni pertama, sistem dunia menunjukkan adanya kriteria partisipasi masing-masing dunia terutama dalam hal hubungan perdagangan yang luas dan kuat, hubungan politik antara negara-negara dalam proses hegemoni dan kekuasan, pertukaran ekonomi, politik, dan juga lingkaran kebudayaan. Kedua, ekonomi dunia terdapat pertukaran barang-barang yang sentralisasi. Ketiga, akumulasi modal yang terjadi tidak hanya disebabkan karena faktor ekonomi namun juga sebagai permintaan politik dan ideologi. Akumulasi modal akan berlangsung secara terus menerus. Keempat, struktur kelas yang terdiri dari tiga kutub dengan tambahan kelas semi-pinggiran. Penjelasan tentang hubungan metropole-satelite dalam hal transfer keuntungan pada kajian sistem dunia membutuhkan penjelasan yang sangat kompleks. Kelima, kekuasaan dan persaingan, ditunjukkan oleh adanya hubungan kekuasaan antar negara dalam sistem dunia.

Keterkaitan antara ketergantungan dengan sistem dunia tergambarkan dalam kasus perkebunan melalui globalisasi sebagai jembatan. Meskipun tampaknya perkebunan telah terintegrasi kedalam sistem ekonomi dunia, namun mata rantai usaha yang berada dalam kontrol perusahaan kecil relatif pendek. Keterkaitan terhadap bahan baku (hulu) dan pemasaran (hilir) pada perusahaan berskala kecil lebih bergantung pada perusahaan lain yang berada di luar kontrol mereka. Dalam kasus kopi, misalnya, perusahaan berskala kecil sangat bergantung dengan para petani kopi dalam pengadaan bahan baku (biji kopi). Para pengusaha tidak mampu melakukan intervensi terhadap kenaikan harga biji kopi yang melonjak selama krisis moneter akibat permintaan ekspor yang meningkat tajam terhadap biji kopi. Para pengusaha terpaksa harus menyesuaikan harga pembelian biji kopi dengan harga internasional yang cenderung terus meningkat seiring dengan melemahnya nilai tukar rupiah terhadap dolar.

Polarisasi ini yang menyebabkan pasar dunia menjadi tidak seimbang. Dimensi komersial (perdagangan barang dan jasa) dan transfer kapital internasional dan migrasi buruh membuat kondisi homogenisasi di tingkat dunia, sehingga menjadi globalisasi ekonomi. Globalisasi kapital dan bukan 
ekonomi berbeda dengan sendirinya dalam dikotomi pusat-pinggiran yang berlanjut semakin buruk.

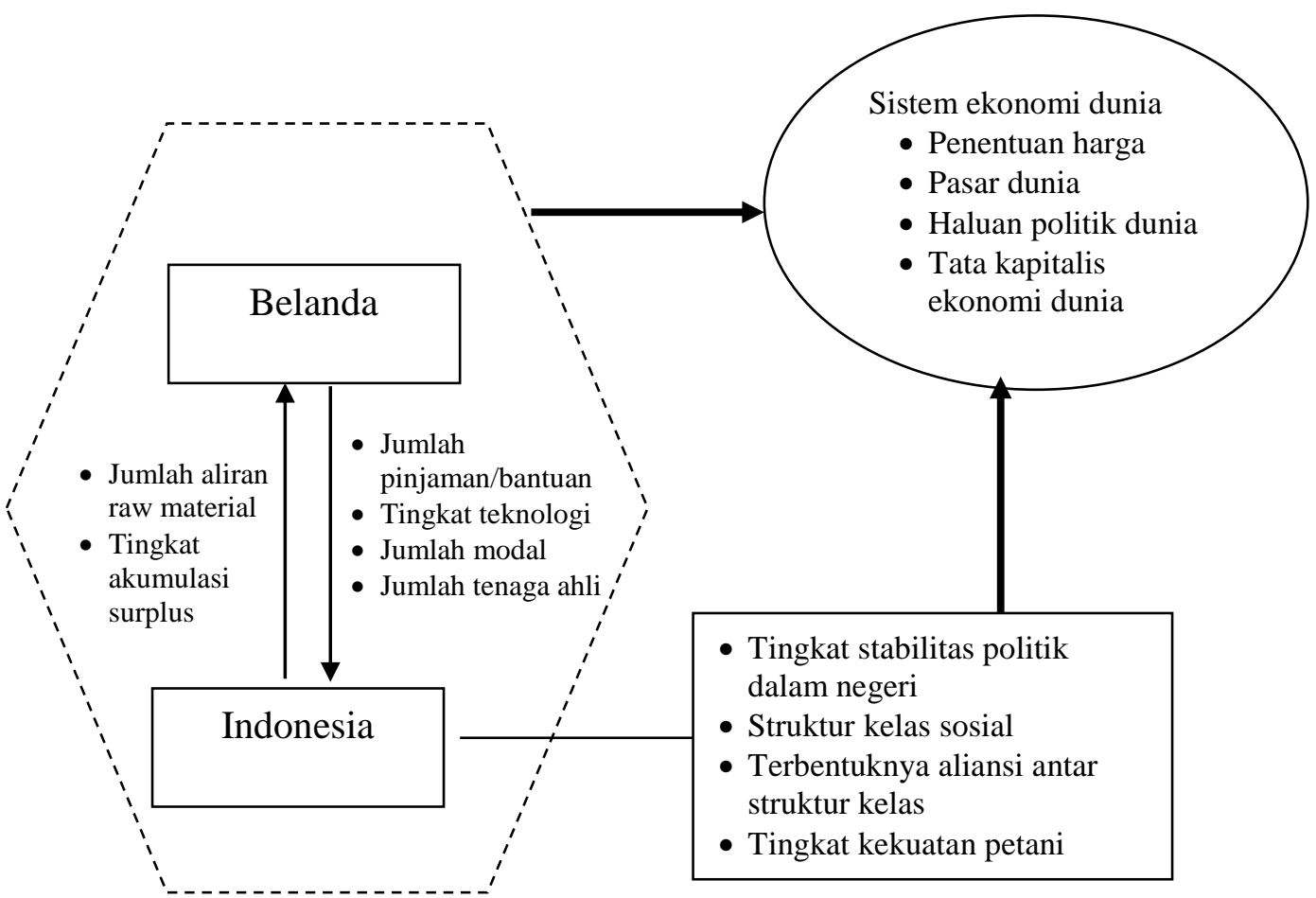

Gambar 1. Kerangka Analisis

\section{PERKEBUNAN SEBAGAI CIRI EKONOMI KETERGANTUNGAN}

Seperti telah dikemukakan di awal bahwa sejarah perkebunan di negara berkembang tidak dapat dipisahkan dari sejarah perkembangan kolonialisme, kapitalisme, dan modernisasi. Perkebunan pada awal perkembangannya hadir sebagai sistem perekonomian baru yang semula belum dikenal, yaitu sistem perekonomian pertanian komersial yang bercorak kolonial dan kapitalistik. Sistem perkebunan diwujudkan dalam bentuk usaha pertanian skala besar dan kompleks, bersifat padat modal (capital intensif), penggunaan areal tanah luas, organisasi tenaga kerja besar, pembagian kerja rinci, penggunaan tenaga kerja upahan (wage labour), struktur hubungan kerja yang rapih, dan penggunaan teknologi modern, spesialisasi, sistem administrasi dan birokrasi, serta penanaman tanaman komersial yang ditujukan untuk komoditi ekspor di pasaran dunia (Kartodirdjo dan Suryo, 1991).

Beckford (1979) bahkan menggambarkan citra perkebunan besar dicerminkan oleh ciri-ciri diantaranya adalah: pertama, sistem ekonomi 
perkebunan besar ditopang oleh dominasi pemikiran bahwa ekspor komoditi pertanian harus diprioritaskan demi pertumbuhan ekonomi nasional. Kedua, perkebunan besar menguasai tanah yang luasnya tak terbatas, atau tak dibatasi. Ketiga, kebutuhan tenaga kerja sangat besar, jauh melebihi suplai tenaga kerja yang ada di pasar karena itu diciptakan mekanisme 'extra-pasar' atau 'nonpasar' (budak belian, kuli kontrak, transmigrasi, dan sejenisnya). Keempat, birokrasi perkebunan besar tidak terjangkau oleh kontrol sosial, karena perkebunan besar merupakan 'enclave' yang terisolasi dari masyarakat (kecuali tebu, di Jawa).

Sejarah ekonomi Indonesia menunjukkan bahwa sistem tanam paksa ditempatkan sebagai titik tolak proses keterbelakangan dan kemiskinan ekonomi rakyat. Proses ekonomi dan struktur sosial yang saat ini tampak merupakan warisan dari struktur pada masa tersebut. Penghapusan sistem tanam paksa dan digantikan oleh sistem perkebunan pada tahun 1870 akibat adanya undang-undang agrarisch wet membuka cara baru dalam mengeksploitasi kekayaan dan pengalihan sebagian surplus ekonomi dari Indonesia ke negara Belanda. Perkebunan-perkebunan besar komoditi primer di Jawa dan Sumatera telah tumbuh sebagai sektor-sektor enclave dalam struktur ekonomi Indonesia. Sektor ini tidak saja dikuasai pihak asing tetapi juga seluruhnya berorientasi ke luar negeri (metropolis di sentrum kapitalis dunia).

Mewarisi karakteristik perkebunan di masa kolonial, sepanjang sejarahnya perkebunan besar dan monokultur diawali oleh upaya investasi di era kolonial untuk memenuhi pasar Eropa. Dengan demikian desain institusi yang diterapkan mengikuti kebutuhan teknologi yang mendasari usaha perkebunan pada waktu tersebut. Ekspor komoditas perkebunan sebagian besar masih dalam bentuk komoditas primer dengan kualitas rendah.

Karakteristik komoditas perkebunan yang lebih mengutamakan pengiriman raw material menampilkan ciri komoditas industri. Sejak awal perkembangannya perkebunan dibangun untuk menyediakan bahan baku yang industrinya berada di luar negeri. Mekanisme seperti itu memberatkan Indonesia dan negara lain yang berada pada posisi negara penyedia bahan mentah karena: pertama, harga riil komoditas perkebunan berfluktuasi cukup besar dengan trend yang terus menurun sejak ratusan tahun yang lalu. Akibat menurunnya harga riil komoditas, posisi ekonomi perkebunan terutama perkebunan rakyat, juga menurun. Kedua, industri hilir perkebunan tetap berada di negara-negara maju. Konsentrasi industri ini membuat hubungan antara negara penghasil bahan baku dengan negara industri sangatlah asimetris. Ketiga, teknologi dikuasai oleh negara-negara maju dengan ilustrasi dominasi seperti diperlihatkan oleh penguasaan paten pada tahun 1995, yaitu paten yang dikuasai oleh negara-negara tropis adalah kurang dari 2 persen.

Ketimpangan yang terjadi disumbang oleh sifat bahan mentah komoditas perkebunan. Petani menanam komoditas yang hasilnya lebih banyak untuk diekspor. Bahan mentah hanya memperoleh keuntungan yang sedikit jika dibandingkan dengan negara yang mengolah bahan mentah menjadi bahan jadi. Ada selisih keuntungan yang diperoleh negara industri dengan cara 
meningkatkan nilai tambah produk melalui pengolahan. Penjelasan demikian memperlihatkan terjadinya kemerosotan nilai tukar.

Struktur kelas sosial yang ada di negara Dunia Ketiga turut melanggengkan kondisi keterbelakangan. Arief dan Sasono (1981) membagi struktur kelas menjadi tuan tanah, petani sedang dan kaya, golongan miskin desa, borjuasi industri domestik, kapitalis dagang, borjuasi kecil, golongan miskin kota, birokrat dan penguasa, dan kapitalis asing. Keterlibatan pribumi yang memiliki kepentingan yang sama dengan kapitalis asing turut mempermudah pengalihan surplus ekonomi Indonesia ke luar negeri. Dalam aliansi ini golongan aristokrat feodal juga memperoleh sebagian surplus ekonomi yang dihasilkan oleh modal asing. Keterbelakangan muncul terutama disebabkan oleh aliansi yang tercipta antara kaum elit dengan kapitalis (Gambar 2). Aliansi-aliansi berikut adalah contoh aliansi-aliansi yang telah bertanggung jawab bagi keterbelakangan kelas yaitu:

1. Aliansi kelas tuan tanah feodal dan petani kaya dengan kelas borjuasi. Akumulasi surplus petani kaya dan tuan tanah feodal dijual kepada kelas borjuasi sehingga terjadi proses perdagangan diantara keduanya. Petani miskin yang menjadi kaum proletar kemudian menjadi sumber buruh murah bagi industri di pedesaan.

2. Aliansi kelas borjuasi dengan kelas kapitalis asing. Penggunaan teknologi di negara berkembang pada dasarnya merupakan upaya negara maju menciptakan ketergantungan. Negara berkembang dijadikan pasar penggunaan teknologi yang sudah tidak dapat digunakan di negara maju. Aliansi antara kelas borjuasi dengan kapitalis asing terlihat ketika kelas kapitalis asing menjual mesin kepada kelas borjuasi dalam rangka hak paten.

3. Aliansi kelas tuan tanah feodal dengan kapitalis asing. Kelas tuan tanah feodal berkepentingan terhadap proses perdagangan komoditi ekspor. Terkait dengan maksud tersebut, golongan ini kemudian berupaya untuk meningkatkan produksi petani kelas menengah kebawah dengan cara menyuntikkan modal. Hal ini menyebabkan banyaknya institusi penyedia modal di pedesaan yang berasal dari dana kapitalis asing.

Gambar 2 menunjukkan bahwa pada setiap masa, surplus ekonomi tetap menjadi tujuan produksi dan tetap mengarah pada golongan tertentu. Ketika surplus ekonomi menjadi tujuan, maka segala upaya kemudian dilakukan untuk tetap dapat mencapai tujuan tersebut. Dalam hal ini peranan luar negeri menjadi signifikan terutama dalam hal penyediaan modal, teknologi dan tenaga ahli yang menyebabkan ketergantungan terhadap luar negeri makin kuat.

Dalam tatanan ekonomi dunia, memandang perkebunan bagi Indonesia tidak boleh terlepas dari lingkungan ekonomi global. Pakpahan (2001) menyatakan bahwa ekspor hasil primer perkebunan mencapai US\$ 4.2 milyar pada tahun 1999 atau sekitar 10.8 persen dari hasil ekspor non-migas; nilai PDB perkebunan, termasuk olahannya mencapai Rp. 167 triliun atau 15 persen dari PDB nasional (1999). Pertumbuhan sub-sektor perkebunan juga relatif tinggi jika dibandingkan dengan sektor lain. Dari perhitungan-perhitungan ekonomi 
demikian, dapat dikatakan bahwa perkebunan merupakan sebuah usaha strategis di Indonesia.

Luar Negeri

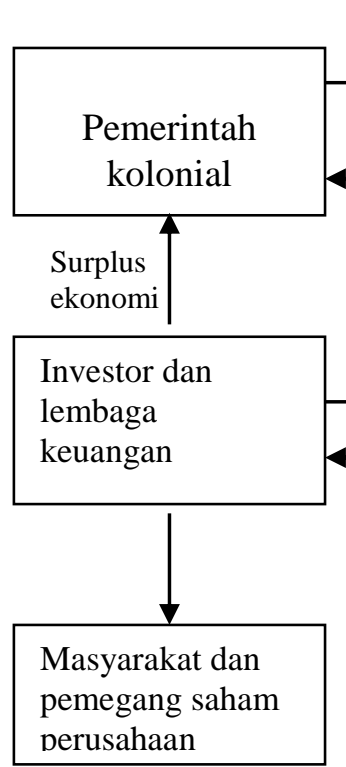

\section{Dalam Negeri}

modal

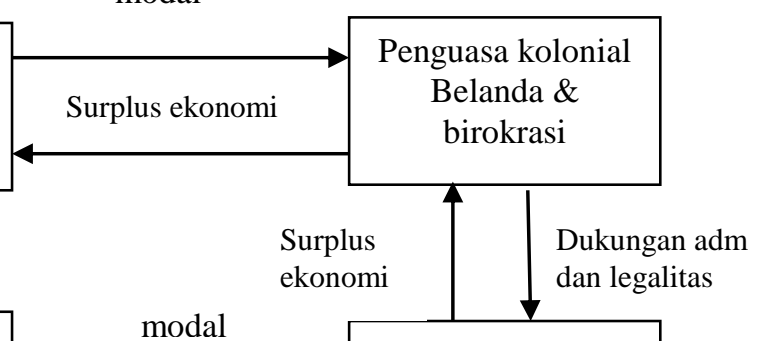

Pemodal asing, pengusaha feodal \& golongan aristokrat lainnya

Surplus
ekonomi

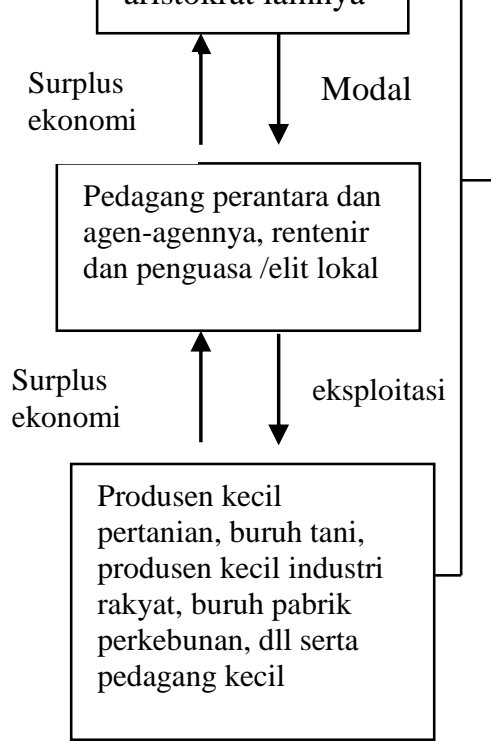

PERKEBUNAN/ NEGARA PRODUSEN

Penetapan harga, pinjaman modal untuk meningkatkan produksi, penjualan teknologi, mempengaruhi politik/kebijakan, penetrasi dan akumulasi kapital

- Multinational polik/kebujakn, penetrasi dan akumulasi kapital Corporations

- Negara kapitalis maju

Pengiriman bahan mentah, pengiriman bahan setengah jadi

Gambar 2. Perkembangan struktur masyarakat dan aliansi yang menyebabkan ketergantungan

Sumber: Kristanto, diolah dengan menggunakan kerangka analisis yang dipilih. 
Terkait dengan konteks hubungan ekonomi Indonesia dengan negara maju, pencapaian pertumbuhan sub-sektor perkebunan dilakukan dengan cara meningkatkan permodalan, bahan baku dan sistem produksi, serta sistem pemasaran. Permodalan diperoleh melalui pinjaman luar negeri atau bantuan dari lembaga keuangan internasional. Hubungan luar negeri yang terjalin memungkinkan Indonesia mampu meningkatkan sistem produksi dengan bantuan teknis dan ekonomi dari negara maju. Sistem pemasaran yang khas untuk komoditas perkebunan juga mendorong Indonesia melakukan berbagai upaya agar komoditi yang dihasilkan laku dipasaran, mulai dari menerapkan potongan harga bagi konsumen hingga melakukan ekspansi pasar internasional.

Dari perkembangannya, terlihat bahwa perkebunan menjadi sektor yang penting dalam menopang perekonomian Indonesia. Namun sayangnya, perkebunan memberi peluang bagi terciptanya ketergantungan negara produsen terhadap negara maju. Persaingan yang semakin ketat antara negara produsen menyebabkan negara maju bebas melakukan permainan harga untuk mendapatkan harga yang paling murah. Belum lagi struktur masyarakat yang ada di negara terbelakang belum stabil sehingga produksi sangat tergantung pada ketersediaan sarana-prasarana serta modal swasta.

Keberadaan perusahaan multinasional (MNC) menyebabkan terjadinya kemungkinan beberapa hal yakni menekan tumbuhnya industri lokal melalui "intrafirm trading" serta mendorong berkembangnya struktur ekonomi dualistik. Ditinjau dari sejarah, globalisasi berasosiasi kuat dengan imperialisme dan MNC merupakan pemain utama dalam dalam ekonomi global. Pasar merupakan penghubung antara negara penghasil bahan mentah dengan MNC. Implikasinya adalah posisi kedaulatan negara-negara berkembang berada di bawah tekanan MNC. Terlebih ketika tuntutan teknologi, modal, tenaga ahli, dan penentuan harga menyebabkan perkebunan harus dapat membina aliansi yang kuat dengan MNC. Kondisi tersebut makin memperlihatkan bahwa "bargaining position" Indonesia ada pada posisi yang lemah.

Dalam konteks pasar global, khususnya pada masa sekarang posisi negara produsen hasil perkebunan belum memiliki kemampuan yang kuat dalam menentukan pasar. Kecenderungan harga riil produk primer perkebunan yang terus menurun dan terjadinya fluktuasi harga komoditas perkebunan yang tajam di pasar internasional sudah cukup membuktikan bahwa peran negaranegara produsen hasil perkebunan sangatlah lemah. Kondisi ini menyebabkan negara produsen memiliki derajat ketergantungan yang tinggi terhadap pasar bebas dan terhadap perusahaan multinasional.

\section{MEKANISME DIPERTAHANKANNYA KETERGANTUNGAN}

Dilihat dari aspek kepentingannya, disatu sisi keberadaan perkebunan besar ini merupakan potensi mengingat adanya kekuatan besar yang sebanding dengan kekuatan ekonomi global. Namun disisi lain, keberadaan perusahaan 
besar telah melahirkan kesenjangan sosial yang membahayakan struktur sosial masyarakat. Gambaran ketergantungan yang terjadi ternyata memiliki dimensi yang rumit tidak hanya menyangkut pola hubungan antar negara namun juga terkait dengan konteks internal negara berkembang. Dalam konteks ekonomi, perkebunan dipandang sebagai agen pembocoran surplus ekonomi negara Dunia Ketiga dan sekaligus dianggap sebagai agen homogenisasi ekonomi internasional yang mengembangkan ideologi world capitalistic economy melalui strategi pembangkitan ekonomi lokal. Karakteristik demikian memicu kaum kapitalis yang dibantu oleh elit lokal menanamkan pengaruhnya pada sektor perkebunan. Implikasinya adalah tetap dipertahankannya perkebunan dengan mengutamakan kedua karakteristik tersebut.

Mekanisme dipertahankannya ketergantungan pada sistem ekonomi perkebunan ditunjukkan melalui kasus perkebunan tebu dan teh. Kedua kasus tersebut menggambarkan sebuah kondisi ketergantungan di tingkat mikro antara petani kecil dengan golongan elit. Kondisi ini dapat ditarik dalam konteks yang lebih besar bahwa ketergantungan yang ada tidak semata-mata berada pada aras mikro, namun juga memiliki andil dalam menciptakan ketergantungan pada aras makro yaitu negara terutama keterkaitannya dengan sistem ekonomi global.

\section{Kasus Perkebunan Teh dan Tebu}

Teh merupakan sebuah komoditas yang lebih banyak dikuasai oleh perkebunan swasta besar. Sejarah membuktikan bahwa teh, sebagai komoditas perkebunan yang bernilai ekonomi memiliki perjalanan yang amat panjang yakni sejak tahun 1728. Masuknya undang-undang agrarisch wet pada tahun 1870 memudahkan lahan-lahan milik petani beralih menjadi lahan milik perkebunan. Dalam perkembangannya, kolusi antara elit desa/wilayah dan pengusaha perkebunan turut mempercepat lenyapnya hak-hak rakyat atas tanah garapan atau milik mereka.

Teh memiliki struktur pasar yang lebih bebas dibanding struktur pasar pada komoditas tebu. Namun demikian kasus teh banyak menimbulkan keterbelakangan. Untuk memenuhi standar ekspor, tenaga kerja dieksploitasi besar-besaran. Ekspor mengharuskan produksi yang dikirim adalah produksi nomor satu sehingga yang tersisa di negara miskin adalah teh dengan kualitas rendah. Dalam hal ini, situasi demikian juga membentuk selera yang dikendalikan oleh ketergantungan. Pada kondisi Indonesia merdeka, pola produksi teh yang dikembangkan tampak tidak jauh berbeda. Perkebunanperkebunan besar menciptakan aliansi dengan pengusaha internasional sedangkan petani kecil menjadi buruh.

Dalam konteks global, teh dipengaruhi oleh struktur pasar. Terbukti pada tahun 1969-1971 terjadi penurunan produksi sebagai akibat merosotnya harga teh di pasaran dunia. Untuk mengatasi kemerosotan harga ini, negara-negara produsen teh dunia membuat kesepakatan untuk membatasi dan mengatur jumlah ekspor teh dan menetapkan kuota-kuota ekspor. Disamping itu, disepakati pula untuk meningkatkan mutu teh ekspor dan mencegah teh

74 | Heru Purwandari. Sistem Ekonomi Perkebunan : Persistensi Ketergantungan... 
bermutu rendah masuk pasaran internasional. Sejak kebijakan tersebut digulirkan, proses produksi diserahkan pada perkebunan besar yang memiliki basis industri. Perkebunan rakyat tidak memainkan peran yang signifikan dan hanya memiliki pangsa pasar di tingkat lokal. Keterkaitan dengan ekonomi dunia dengan sendirinya menjadi berkurang. Teh yang memiliki kaitan dengan ekonomi dunia adalah teh yang penanganannya dikendalikan oleh perkebunan besar swasta. Kondisi tersebut tidak berubah hingga kini sehingga hubungan antara perkebunan besar dengan perkebunan rakyat khusus komoditas teh merupakan bentuk hubungan yang relatif tetap sifatnya.

Kasus lain yang dapat dilihat dalam kaitannya dengan mekanisme dipertahankannya ketergantungan adalah perkebunan tebu. Melalui prinsip tanam paksa, pemerintah kolonial berhasil memaksa petani untuk menanam tebu diatas lahannya. Dalam hal ini petani mengalami eksploitasi yang menyebabkan kemiskinan dan keterbelakangan. Sebagai akibatnya, petani enggan menanam komoditas tebu. Ini yang kemudian memaksa pemerintah untuk merubah pendekatan. Program yang kemudian ditawarkan adalah Tebu Rakyat Intensifikasi (TRI). Program ini ternyata masih menyisakan kurangnya kebebasan petani untuk berproduksi. Pemaksaan yang dilakukan tidak hanya bermakna mengejar target produksi gula, namun juga melekat pada unsur power structure dengan latar belakang kepentingan politik birokratis tertentu (Bachriadi, 1995).

Proses produksi yang tidak memenuhi ketentuan standar misalnya, proses tebang angkut yang tidak tepat waktu, teknologi pengolahan yang telah usang, rendahnya daya serap pabrik, mutu tebu yang menurun, dll mempengaruhi produktivitas dan efisiensi pabrik gula dalam menghasilkan hablur gula. Akibatnya harga gula Indonesia tidak dapat bersaing dengan gula impor. Kondisi demikian diperparah dengan terakumulasinya surplus hanya pada golongan elit dan para cukong-cukong berlahan luas yang memiliki modal kuat untuk mengatur harga tebu di tingkat petani. Dalam konteks makro, keberadaan cukong tersebut terkait dengan para elit politik dan pemerintah yang ingin tetap mempertahankan tingginya harga gula sehingga memberi aspek legalitas untuk mengimpor gula. Ini bukan masalah kecil namun menyangkut keterkaitan Indonesia dalam posisi internasional.

Pada kasus teh, tampak bahwa perkembangan perkebunan tidak tampak signifikan berbeda antara masa kolonial dengan masa kemerdekaan. Petani kecil tetap menjual produk dalam bentuk komoditas primer tanpa terlebih dahulu mengalami proses pengolahan. Ini menyebabkan nilai tambah produk tidak pernah dinikmati oleh petani. Petani kecil mengalami ketergantungan dalam menjual hasil kebunnya.

Pada kasus tebu, ada perubahan arah ketergantungan. Jika pada masa kolonial, melalui tanam paksa pemerintah Belanda memperoleh surplus ekonomi, maka hal tersebut tampak berubah pada masa kemerdekaan. Dalam hal ini peran pemerintah mulai tampak. Kaum elit yang ada di negara Dunia Ketiga merupakan pihak di periferi yang melanggengkan ketergantungan. 
Persamaan kepentingan yang sama antara elit dalam negeri dengan kapitalis asing menciptakan hubungan yang setara antara kedua belah pihak tersebut.

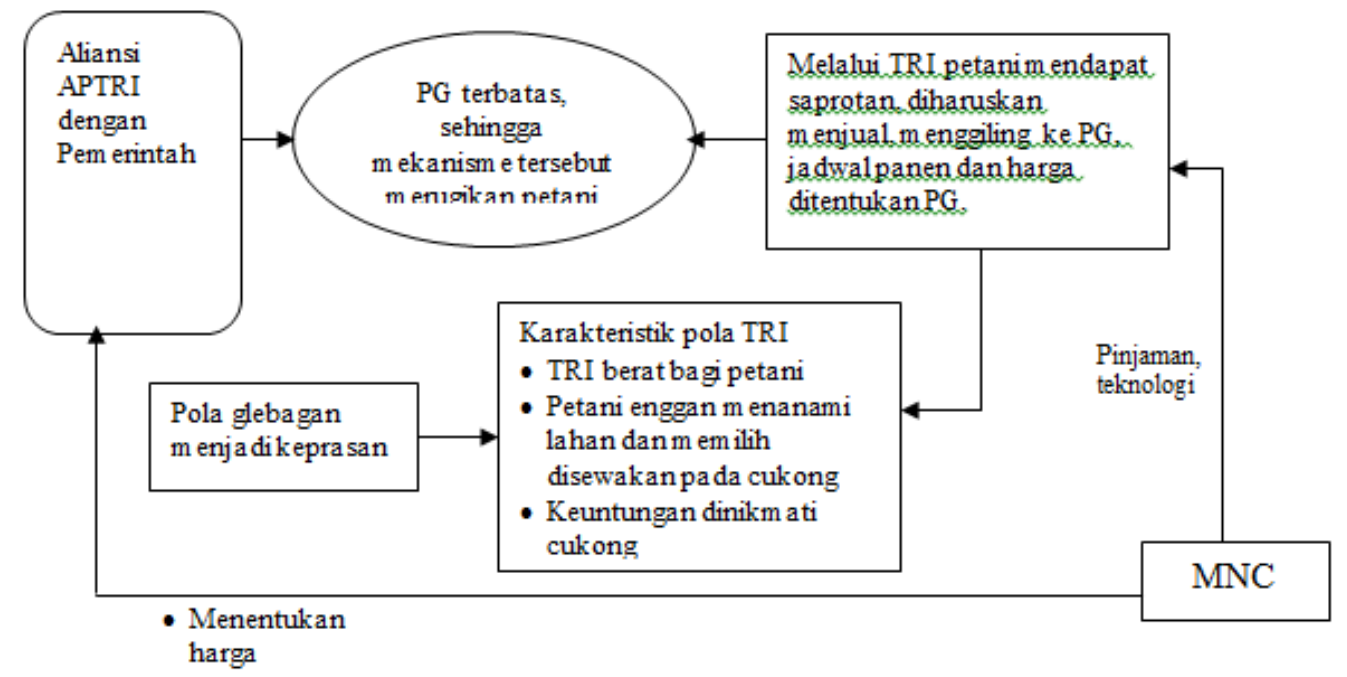

Gambar 3. Mekanisme dipertahankannya ketergantungan

\section{SIMPULAN}

Ketergantungan yang terjadi pada sektor perkebunan terbukti tidak hanya ditentukan oleh proses pengambilan surplus ekonomi oleh negara maju namun juga diwarnai oleh faktor internal dalam negara berkembang. Faktor internal yang dimaksud adalah struktur sosial-politik yang melanggengkan pola-pola ketergantungan.

Pada masa awal kolonial ketergantungan yang terjadi lebih pada hubungan antara Indonesia dengan Belanda tanpa dipengaruhi oleh sistem ekonomi dunia. Kasus perkebunan teh menunjukkan tetap terpeliharanya ketergantungan kolonial. Tidak ada perubahan yang berarti dalam proses penyerapan surplus. Melalui mekanisme yang sama komoditas teh menjadi jembatan dipertahankannya ketergantungan. Berbeda dengan kasus perkebunan pada masa kini yang sudah mulai memperlihatkan pengaruh faktor internal negara dan juga diwarnai oleh konteks ekonomi global. Melalui kasus perkebunan tebu hal tersebut berusaha ditunjukkan. Diawal perkembangannya (masa kolonial) tebu memiliki pola ketergantungan yang mirip dengan pola ketergantungan pada perkebunan teh. Namun pola tersebut kemudian berubah menjadi ketergantungan model baru dimana golongan elit - dalam hal ini perusahaan lokal dan negara - turut berperan melalui penerapan kebijakan baru. Ketergantungan model baru yang terjadi dimana didalamnya muncul keterlibatan pemerintah tetap tidak mampu menahan pengaruh global yang dihembuskan oleh pasar internasional. Meskipun negara berperan, namun 
impor gula terus berlanjut. Hal tersebut terkait dengan "perjanjian" pemerintah dengan kapitalis dunia yang ingin menancapkan kukunya di Indonesia. Impor gula merupakan korbanan Indonesia jika ingin mempertahankan masuknya modal asing untuk membiayai perkebunan sebagai sektor strategis di Indonesia.

Keterlibatan negara secara aktif di dalam implementasi hubungan produksi menunjukkan bahwa upaya peningkatan hasil produksi pertanian dari sub-sektor agribisnis memiliki muatan politis, disamping sejumlah kepentingan ekonomis. Tangan-tangan kapitalis yang diwakili oleh perusahaan multinasional kemudian mendapat keuntungan dari pola hubungan antara petani dan negara. Disatu pihak, negara sangat tergantung pada kaum kapitalis untuk dapat meningkatkan produksi dengan menekan petani, dilain pihak negara tidak memiliki kekuatan untuk mengontrol mekanisme pasar internasional untuk memperoleh keuntungan dari hubungan perdagangan yang terjadi.

Akhirnya, perkebunan hanya digunakan sebagai alat kaum kapitalis untuk menciptakan ketergantungan dari negara produsen terhadap negara konsumen tanpa disadari oleh pemerintah negara produsen itu sendiri. Kepentingan ekonomi tidak lagi menjadi satu-satunya tujuan bagi kaum kapitalis, namun lebih jauh dari itu adalah penguasaan atas kekuasan itu sendiri. Untuk tetap mempertahankan kekuasaan atas negara produsen, maka kaum kapitalis seolaholah memberikan berbagai bantuan dengan alasan untuk memfasilitasi negara produsen dalam meningkatkan produksinya. Namun dari sudut pandang teori ketergantungan, semua itu dipandang sebagai sebuah mekanisme dipertahankannya kondisi ketergantungan ekonomi negara miskin terhadap negara maju.

Hal ini berarti bahwa pembenahan struktur dalam negeri harus menjadi prioritas untuk mengurangi ketergantungan yang ada. Aliansi yang selama ini terbentuk antara elit lokal dengan pengusaha besar kaki tangan kapitalis harus dihapuskan dan diganti dengan aliansi antara petani kecil dengan elit lokal untuk bersama-sama melawan struktur pasar internasional yang sesungguhnya merugikan baik petani kecil maupun elit lokal. Kebijakan pemerintah yang terlalu berorientasi pada ekonomi dan perkebunan besar terutama di sektor perkebunan juga harus dibatasi agar negara tidak tergantung pada modal dan teknologi dari luar. Pemihakan pemerintah harus ditujukan pada keberadaan perkebunan rakyat yang justru jika dilihat memiliki keterkaitan yang kurang kuat dengan internasional. Kurangnya keterikatan ini justru menjadi modal kemandirian ekonomi sebuah negara

\section{DAFTAR PUSTAKA}

Atmosudirdjo, Prajudi. 1983. Sejarah Ekonomi Indonesia: dari Segi Sosiologi Sampai Akhir Abad XIX. Pradnya Paramita. Jakarta 
Arief, Sritua dan Adi Sasono. 1984. Ketergantungan dan Keterbelakangan: Sebuah Studi Kasus. Penerbit Sinar Harapan. Jakarta

Bachriadi, Dianto. 1995. Ketergantungan Petani dan Penetrasi Kapital. Akatiga. Bandung

Beckford, G.L. 1972. Persistent Poverty: Underdevelopment in Plantation Economies of the Third Worl. Oxford University Press. London

Cardoso, Fernando. 1982. "Dependency and Development in Latin America" Pp 112127 in Hamza Alavi \& Teodor Shanin (Eds). Introduction to the Sociology of Developing Societies. New York: Monthly Review Press.

Frank, Andre Gunder. 1984. Sosiologi Pembangunan dan Keterbelakangan Sosiologi. Pustaka Pulsar. Jakarta

Frank, Andre Gunder. 1969. "The Development of Underdevelopment" in Latin America: Underdevelopment or Revolution. New York: Monthly Review Express

Galtung, Johan. 1980. "A Structural Theory of Imperialisme" Pp 261-298 in Ingolf and Anthony R. De Souza (Eds) Dialectics of Third World Development. New York: Montelair

Kartodirdjo, Sartono dan Djoko Suryo. 1991. Sejarah Perkebunan di Indonesia: Kajian Sosial Ekonomi. Aditya Media. Yogyakarta

Kristanto, Heri. 2003. Menimbang Sejarah Dalam Ekonomi Indonesia. Jurnal ekonomi Rakyat. Th. I - No. 11 - Januari 2003

O'Brien, Philip J. 1975. A Critique of Latin American Theories of Dependency. In I.Oxaal, T. Barentt \& Booth (Eds) Beyond the Sociology of Development. London:

O’Malley, William. 1988. Perkebunan 1830-1940: Ikhtisar dalam Sejarah Ekonomi Indonesia. Booth, Anne., et al. (Peny). LP3ES. Jakarta

Pakpahan, Agus. 2002a. Membangun Perkebunan Abad 21: Membalik Arus dan Gelombang Sejarah (sebuah konsep Strategi Pembangunan Perkebunan yang Partisipatif, Produktif, Efisien, Berkeadilan, dan Berkelanjutan) dalam Membalik Arus dan Gelombang Sejarah Perkebunan Indonesia. 2002. Kumpulan Makalah. Edisi I

Pakpahan, Agus. 2000b. Globalisasi dan Pemanfaatan Sumberdaya Alam (Perkebunan): apakah MNC Sebagai Ancaman atau Peluang? dalam Membalik Arus dan Gelombang Sejarah Perkebunan Indonesia. 2002. Kumpulan Makalah. Edisi I

Pakpahan, Agus. 2000c. Globalisasi dan Pemanfaatan Sumberdaya Alam (Perkebunan): Internalisasi Otonomi Daerah untuk Kemajuan Agribisnis Perkebunan dalam Membalik Arus dan Gelombang Sejarah Perkebunan Indonesia. 2002. Kumpulan Makalah. Edisi I

Pakpahan, Agus. 2000d. Peranan HGU dalam Pengembangan Perkebunan Besar dalam Pola Penguasaan dan Pola Usaha serta Pemberdayaan BPN dan Pemda

78 | Heru Purwandari. Sistem Ekonomi Perkebunan : Persistensi Ketergantungan... 
dalam Rangka Partisipasi Rakyat di Sektor Perkebunan. Soetarto, E, et al. (peny). Prosiding Lokakarya. Pusat Kajian Agraria. Bogor

Pakpahan, Agus. 1999. Kebijaksanaan dan Langkah-langkah Pengembangan

Kemitraan Bidang Perkebunan dalam Membalik Arus dan Gelombang Sejarah Perkebunan Indonesia. 2002. Kumpulan Makalah. Edisi I

Roxborough, Ian. 1986. Teori-teori Keterbelakangan. LP3ES. Jakarta

Suwarsono dan Alvin Y. So. 1991. Perubahan Sosial dan Pembangunan di Indonesia.

LP3ES. Jakarta 